\title{
Corporate governance and firm performance in an emerging economy context: new evidence from India
}

\author{
Nidhi Bansal* and Anil K. Sharma \\ Department of Management Studies, \\ Indian Institute of Technology Roorkee, \\ Roorkee, Uttarakhand, 247667, India \\ Email: nidhibansal111@gmail.com \\ Email: aanilkssharma@gmail.com \\ *Corresponding author
}

\begin{abstract}
The new Companies Act of India 2013 has laid emphasis on the role of an audit committee and remuneration committee in Indian firms. Considering these changes, the present study examines the relationship between corporate governance mechanisms and firm performance of Indian firms listed publicly on the National Stock Exchange CNX-500 during the period 2004-2013; including two relatively underexplored variables - audit committee and remuneration committee. The results are cross-checked for the period of the post-enactment of the new Companies Act, that is, 2014-2018. In order to investigate the relationship, panel feasible generalised least squares method is applied. The major findings of the study suggest that promoter shareholding, the frequency of audit committee meetings, and audit committee independence have a significant and positive impact on the performance of firms. These new findings would be useful for organisations similar to the ones considered in the study in other lower-middle income economies or small and medium enterprises which are not listed on stock exchanges.
\end{abstract}

Keywords: corporate governance; audit committee; remuneration committee; firm performance; emerging economies; India.

Reference to this paper should be made as follows: Bansal, N. and Sharma, A.K. (2019) 'Corporate governance and firm performance in an emerging economy context: new evidence from India', Int. J. Comparative Management, Vol. 2, No. 2, pp.123-147.

Biographical notes: Nidhi Bansal is a $\mathrm{PhD}$ candidate in Accounting and Finance at the Department of Management Studies, Indian Institute of Technology Roorkee. She has five years of experience in academics and her teaching and research interests include corporate governance, financial management, financial markets, and corporate finance. She has published and reviewed several research papers for various national and international journals of repute.

Anil K. Sharma is a Professor of Finance at the Department of Management Studies, Indian Institute of Technology Roorkee. He has been a Visiting Faculty at the prestigious Asian Institute of Technology, Bangkok and is a registered consultant to the Asian Development Bank, Manila. His teaching and research interests include corporate finance, management accounting, financial management, working capital management, financial accounting, and risk management. He has published numerous research articles in refereed national and international journals of repute and is on the reviewers' panel for many reputed international journals. 


\section{Introduction}

The formation and functioning of companies in different countries are governed by the respective acts and regulations applicable in those nations. In practice, shareholders appoint a board of directors to manage the affairs of the firm on their behalf. However, there are times when a conflict of interest between shareholders and managers give rise to agency problems (managers do not work in the interest of owners; Abdel-Meguid et al., 2014; Globerman et al., 2011; Jensen and Meckling, 1976). For example, there are cases of agency problems in India as could be found in National Spot Exchange Ltd/ Financial Technologies (India) Ltd. case; or from the activities of Chanda Kochhar (Former CEO of ICICI Bank) which were in favour of her husband's company; or the deeds of Cyrus Mistry of Tata Sons Ltd which were not in favoyr of investors. To overcome agency problems, regulators proposed to compensate agents based on performance (Al-Najjar, 2017; Tosi and Gomez-Mejia, 1989). This measure, however, brought along, its own set of challenges. A major problem that arose was that managers started focusing more on short term performance (at the expense of long term interests) of the firm so as to get good compensation and enhance personal reputation (Murphy, 1999; Hermalin and Weisbach, 2017). Further, in order to make the firm's performance look better, managers' resort to manipulation of financial information also (Efendi et al., 2007). Thus, there was misuse and mismanagement of funds invested by investors. Policymakers felt the need to strengthen corporate governance measures and, therefore, suggested establishing a monitoring mechanism in the form of a remuneration committee and audit committee comprising mainly non-executive or outside directors.

Remuneration committee was suggested for limiting the incentives provided to managers and inside directors (Conyon and Peck, 1998). Setting up of the audit committee was aimed at preventing manipulation of financial information (Zhang et al., 2007). Scams such as Olympus (Flannery, 2011), Cadbury, Nigeria (Abdullahi et al., 2010), Satyam, Saradha, Sahara, etc. (Bhasin, 2013; Singh et al., 2010; Sen et al., 2014) underscore the need of having strong corporate governance measures. These scams call for increased role and responsibilities of independent directors and audit committees in order to more effectively monitor the working of management (Yuan, 2011). In a study, Bhasin (2012) identified that out of 40 major capital markets there are only nine capital markets that do not form an audit committee. This means that the rest of the 31 countries have accepted the importance of the audit committee in protecting the interest of all stakeholders thereby improving firm performance.

\subsection{Research gaps and objectives}

Corporate governance is a promising research for academic scholars and also an area of interest among the policy makers, regulators, governments, international financial institutions, etc. It is important for the economic development of a country as well as for a significant policy issue for many countries (Claessens and Yurtoglu, 2013; Hoskisson et al., 2013). Financial scams, policy changes etc., have greatly affected the corporate all over the world including Asia (Balasubramanian et al., 2010; Chen et al., 2013; Dayanandan et al., 2019; Globerman et al., 2011). Studies assert that the presence of an audit committee leads to increased investor confidence in the firm (Smaraidos et al., 2018; Kueppers and Sullivan, 2010). After amendments in the new Companies Act of India 2013 (hereinafter, ICA 2013), Clause 49 of the listing agreement was also revised, 
which suggested increasing the role and responsibilities of the audit committee and remuneration committee.

Although previous studies have examined the relationship between various elements of corporate governance and firm performance, results remain inconclusive (Claessens and Yurtoglu, 2013; Filatotchev et al., 2013; Hoskisson et al., 2013; Schiehll and Martins, 2016). The various elements considered are board structure (Ameer et al., 2010; Dharmadasa et al., 2014; Brickley et al., 1997), ownership structure (Ameer et al., 2010; Nuryanah and Islam, 2011), managerial ownership (Abdel-Meguid et al., 2014; Nuryanah and Islam, 2011) promoter shareholding, audit committee independence, gender diversity, etc. (Chen et al., 2013; Dayanandan et al., 2019; Filatotchev et al., 2013). Predominantly previous literature, for example, Prentice and Space (2007), Pucheta-Martinez and de Fuentes (2007) had emphasised on analysing the impact of the audit committee on financial reporting process but studies related to its impact on financial performance of a firm are limited. Studies have been conducted in different parts of the world and many researchers have studied different variables to understand the concept of corporate governance. However, the two important variables i.e. audit committee and remuneration committee and their role in better corporate governance are least studied (Dayanandan et al., 2019; Schiehll and Martins, 2016). Therefore, one important reason for the present study is to include these important variables and to understand their impact on the governance of the Indian corporate sector. The focus of this study is to identify the impact of two important characteristics of audit committee, i.e., independence of audit committee and frequency of meetings of audit committee along with other board characteristics on financial performance of a firm. Further, the formation of the remuneration committee has become a mandatory requirement in India after the incorporation of ICA 2013. Therefore, the need was felt to study the component along with other components of corporate governance. The purpose of this study is to explore the importance of more focused amendments made in revised corporate governance codes in ICA 2013 using the data available for past years and checking the outcome with present years.

The study makes a significant contribution to the existing body of literature by examining the relationship (in an Indian context) between firm performance and corporate governance mechanisms, where audit committee and remuneration committee are two variables that remain relatively underexplored hitherto (see for studies in the Indian context, Balasubramanian et al., 2010; Dayanandan et al., 2019). Studies considering these two enablers are in the inception stage in India. Further, the sample considered for the study represents $94 \%$ of the total market capitalisation (NSE India) which symbolises a major portion of the total market and the results based on such sample can be generalised on other listed and non-listed companies of India and other lower-middle-income economies. Apart from exploring the relationship between corporate governance mechanism and firm performance based on the data for the years 2004-2013, i.e., before the enactment of ICA 2013, it is also checking the results after the application of amendments made through ICA 2013. Based on such sample, it may be said that the relationships explored in the study may be taken as strong indicators of relationship mechanisms between corporate governance components and firm performance for similar and smaller organisations in India and other lower-middle-income economies. 
The findings of the present study are that promoter shareholding and audit committee independence are the two components of corporate governance that have a significant effect on firm performance. Further, the study found that independent directors in the board had significant but negative association with Tobin's $Q$ whereas frequency of audit committee meetings was positively and significantly (at 10\% significance level) associated with Tobin's Q. Rest of the components of corporate governance considered in the study were found to have an insignificant relationship with any of the measures of the firm performance.

The rest of the article is structured as follows. Section 2 reviews existing literature and formulates hypotheses with respect to attributes of board structure, audit committee, and remuneration committee. Section 3 defines the research methodology, including dependent and explanatory variables, and estimation model considered in the study. Section 4 presents results and discussions as well as additional analyses. Section 5 discusses implications of the study. Section 6 highlights major findings and suggests limitations of the research.

\section{Theoretical background and hypotheses development}

The role of the board in decision making can be understood based on the theoretical framework of corporate governance. Basically, this involves four theories.

1 Agency theory: In this board is responsible to monitor management for the interest of shareholders (Fama and Jensen, 1983).

2 Resource dependency theory: In this board helps the management in procuring resources for achieving organisational goals (Hillman and Dalziel, 2003).

3 Stakeholder theory: It emphasises the importance of other groups such as suppliers, customers, community etc. vital for the functioning of an organization (Freeman, 1984).

4 Stewardship theory: In it, managers are considered stewards of the owners i.e. they are not under the control of owners but work for the benefit of them (Donaldson and Davis, 1991). Going forward, this section sheds light on studies carried out on the relationship between the various components of corporate governance and firm performance, and on the basis of literature, develops hypotheses.

\subsection{Board size and firm performance}

Board size is one of the important elements of corporate governance mechanisms that reduce agency problems by ensuring the proper conduct of the agents of business (Field and Mkrtchyan, 2016). Larger board size improves firm performance due to their diversity in terms of knowledge, skills, and experience (Ciftci et. al., 2019; Ghasemi and Ab Razak, 2016). Literature does not provide a definite standpoint with respect to the size of the board and its impact on firm performance. However, emerging economies have their own jurisdictional structures. Although Mauritius code of corporate governance does not define a number for board size, it states that "the board should be of sufficient size to meet the requirements of the business but should not be so large as to be unwieldy". In Malaysia also, there is no specific board size (Securities Commission 
Malaysia, 2012). Bangladesh code of corporate governance requires firms to have board members between five and 20 (Securities and Exchange Commission Bangladesh, 2012) whereas in Thailand it should be between five and 12 (Stock Exchange of Thailand, 2012). In India, it should be between three and 15 for a public limited company (Chapter XI, Indian Companies Act 2013).

Several studies have been conducted in different countries to examine the relationship between board size and firm performance. In a study of ten developed countries considering the market to book value of equity for 12 months, De Andres et al., (2005) found a negative association between board size and firm value. Similar results were found by Paniagua et al. (2018), Al-Najjar, (2017), Cheng (2008) and Pamburai et al. (2015). On the other hand, several studies have stressed that large boards are in a better position to gain diverse opinions and get broader perspective with respect to issues which is restricted in case of smaller boards (Ujunwa, 2012; Saibaba and Ansari, 2012; Coles et al., 2008). Kumar and Singh (2013) conducted their study in the Indian context and concluded that the ideal board size for Indian companies was 10 or more directors. Saibaba and Ansari (2012) found a significant and negative relation between board size and firm performance, and using spline regression found that board size for Indian companies should be between nine and 20. It is clear that different studies have given mixed results with respect to the relationship between board size and performance, and that the relationship differs with context. Thus, we propose the following hypothesis:

Hypothesis 1a There is a negative relationship between board size and firm performance.

\subsection{Board independence and firm performance}

Fama and Jensen (1983) suggested that independent directors can improve board monitoring and performance of firms by reducing agency costs of firms. According to agency theory, a board having more independent directors (i.e., board members not related to promoters or directors of the company) would probably be more effective in monitoring the company's CEO and other executive directors. Based on the arguments above, it can be said that board independence might be a probable substitute for formal engagement by large shareholders (Jackson, 2010). Few studies such as Ameer et al. (2010), Dharmadasa et al. (2014) and Kao et al., (2019) concluded that a greater number of independent directors on the board and in different committees improve the monitoring capacity of the firm along with its profitability. It may also increase the stock prices of a firm (Leung et al., 2014). Emerging economies face a weaker external governance mechanism. Therefore to protect the interest of minority shareholders, they recommend more independence in the boards of companies. In Bangladesh, at least 1/5 of the total number of directors should be independent (Securities and Exchange Commission Bangladesh, 2012) whereas in Mauritius at least two directors need to be independent directors (Ministry of Financial Services, Good Governance and Institutional Reforms, 2016). The jurisdiction of Thailand mandates that listed companies in Thailand should have at least 50\% of the total directors independent (Stock Exchange of Thailand, 2012). In Malaysia, at least one third board members must be independent (Securities Commission Malaysia, 2012). In Sri Lanka at least two directors or one-third of the total board members should be independent (whichever is higher) (The Securities and Exchange Commission of Sri Lanka and The Institute of Chartered Accountants of 
Sri Lanka, 2013). In India, before the incorporation of ICA 2013, independence of the board depended on the chairman of the board. "If the Chairman is a non-executive director, at least one-third of the Board should comprise of independent directors and in case he is an executive director, at least half of the Board should comprise of independent directors" (Clause 49). After incorporation, ICA 2013 requires that every listed company must have at least one-third of the total board members as independent directors.

Researchers such as Brick and Chidambaran (2010) and Coles et al. (2008) stated that the advisory role of independent directors (as compared to monitoring role) led to greater profits. Several other researchers (Balasubramanian et al., 2010; Meyer and de Wet, 2013; Sarkar et al., 2006) are of the view that due to lack of complete information about the firm, independent directors cannot contribute to profits. Moreover, it is the competence of the board that matters more than its independence. However, it is still unclear how board structure influences critical decisions of the firm and thereby firm performance. Therefore, it requires further investigation. Keeping this in mind, we propose the following hypothesis:

Hypothesis $1 \mathrm{~b}$ There is a positive relationship between board independence and firm performance.

\subsection{Promoter shareholding and firm performance}

Promoter shareholding, also known as founding family ownership, is a prerequisite to align the interest of founders with that of other investors (Jensen and Meckling, 1976). Studies show that due to the personal interest of promoters in firms, they concentrate on improving long term firm profitability (Casson, 1999). Researchers such as Andres (2008) and Kumar and Singh (2013) also found that a greater degree of ownership improves shareholder profit. McConnell et al. (2005) found a nonlinear relationship between promoter ownership and firm value. Chen et al. (2005) observed 412 firms listed in Hong Kong stock exchange and found no association between founders' ownership and firm value when measured by Return on Equity, Return on Assets and dividend payment. Sarkar and Sarkar (2008) concluded that promoter shareholding did not influence firm value in case of low growth firms; however, promoter shareholding did show an impact on firm value in case of high growth firms. It is clear from the discussion above that the relationship between promoter shareholding and firm performance varies with context. Therefore, we propose the following hypothesis:

Hypothesis 1c There is a positive relationship between promoter shareholding and firm performance.

\subsection{CEO duality and firm performance}

Developed countries like the US do not favour a common leadership structure where the position of CEO and chairman of the board is held by the same person (Krenn, 2014). In emerging countries, some jurisdictions remain silent over the matter of CEO duality. However, Mauritius code of corporate governance favours a unitary structure and Malaysia recommends that the two positions should be held by two different persons. Several studies have been conducted to examine the effect of dual position on firm 
performance, and results have been mixed. Daily and Dalton, (1997) and Brickley et al. (1997) found no significant relationship between dual position and firm performance on the basis of stock prices of firms. Some studies such as Donaldson and Davis (1991) pointed out that duality increased performance and prevent conflict between parties while some others (Kao et al., 2019; Elmagrhi et al., 2017; Khan et al., 2017; Ujunwa, 2012; Kaymak and Bektas, 2008) censure the dual role of chair-CEO stating, it would negatively affect the interest of shareholders. According to Duru et al. (2016) several firms' activist shareholders (e.g., Goldman Sachs, News Corp, and JP Morgan Chase) had proposed prohibition of CEO duality. However, some firms were in support of CEO duality that enhances the value of a firm. Rhoades et al. (2001) suggested that unity of command was more important than the independence of board in firms where performance was weak. Keeping in mind the arguments of developed countries, we propose the following hypothesis:

Hypothesis 1d There is a negative relationship between CEO duality and firm performance.

\subsection{Audit committee independence and firm performance}

The efficacy of the audit committee and its contribution to governance and performance of firms have received much attention worldwide from regulators, government bodies and researchers (Nuryanah and Islam, 2011). According to the Blue Ribbon Report (2002), the audit committee plays a vital role in monitoring board activities. As mentioned in section 177 of the new Companies Act of India (2013), "Audit committees are a measure of ensuring self-discipline, constituted with the object to strengthen and oversee management in public companies and to ensure that the board of directors discharges their functions effectively." The Act acknowledged the significance of an audit committee and assigned to it added roles and responsibilities. Independence of the audit committee does, to a great extent, assure strict vigilance over managerial activities in a firm. Jurisdictions of emerging economies have their own structure for audit committee composition with a major emphasis on its independence. Mauritius and Bangladesh recommend inclusion of at least one independent director in the audit committee whereas China recommends more than $50 \%$ independent directors in the audit committee. India and Korea recommend a minimum of three directors or two-thirds of the total members as independent directors (whichever is higher). In Malaysia, the majority of the total audit committee members, including the chairman, should be independent. Israel and Thailand code of corporate governance recommend $100 \%$ independent directors in audit committee (SOX Act, Malaysian Companies Act, Securities, and Exchange Act of Thailand, Companies Ordinance of Hong Kong, China, Companies Act of India, etc.).

Arslan et al. (2014), Carcello et al. (2009) and Klein (1998) provided evidence in their studies that quality of audit reports and firm performance improved in firms with more independent audit committees. The above discussion emphasises a positive relationship between audit committee independence and firm performance. Therefore, we propose the following hypothesis:

Hypothesis $2 \mathrm{a}$ There is a positive relationship between audit committee independence and firm performance. 


\subsection{Audit committee meetings and firm performance}

Al-Mamun et al. (2014) suggested that a firm in which frequency of audit committee meeting is high was more vigilant about investors' interest and fewer incidents of financial statement frauds occurred in such firms. Raghunandan and Rama (2007) emphasise that frequency of audit committee meeting can be used as a measure for assessing the alertness of the audit committee in monitoring activity. More meetings of the audit committee ensure that audit quality is positively related to the information disclosed in the annual report of a company (O'Sullivan et al., 2008). One of the recommendations of the Blue Ribbon Committee (BRC, 2002) report is the need for frequent audit committee meetings (Bryan et al., 2004). Emerging economies more or less agree on the same number of meetings required to be held by an audit committee in a year. Bangladesh, Mauritius, Malaysia, and India recommend minimum four audit committee meetings in a year whereas Sri Lanka recommends that audit committee must meet at least three times in a year. Menon and Deahl (1994) emphasised on two essential audit committee characteristics - its independence and frequency of meeting - to decide if the board had visible faith in the audit committee that it could regulate and control the management; it was found that these attributes could improve monitoring and performance of a firm.

It is thus clear that the majority of studies have stressed that the Frequency of Audit Committee Meetings is an influencer of firm performance. Thus, we formulate the following hypothesis:

Hypothesis 2b There is a positive relationship between the frequency of audit committee meetings and firm performance.

\subsection{Remuneration committee and firm performance}

In 1998, the Cadbury Committee recommended the formation of remuneration committees in companies that could compensate for directors (London Stock Exchange, 1998). Section 178(1) of Indian Companies Act (2013) also mandates the formation of Nomination and Remuneration Committee which "assists the board of directors in the formulation of remuneration policies for directors, key managerial personnel and other employees. The committee also recommends criteria for determining qualifications, attributes and independence of a director." The jurisdiction of China, Morocco, Sri Lanka, Nigeria, and Tanzania recommend the mandatory formation of the remuneration committee. However, there are no specific requirements in this regard in Kenya, Israel, Bangladesh, Tunisia, Pakistan, Romania, and Columbia. Studies such as Laksmana (2008) and Conyon and Peck (1998) found that it can contribute towards aligning the interest of the management with that of shareholders by defining compensation mechanisms and creating sound governance in the firm. Relatively fewer studies have been conducted to judge the efficiency of the remuneration committee in enhancing the performance of firms. Klein (1998) reported that the remuneration committee was positively associated with firm performance.

On the basis of the discussion above, we propose the following hypothesis:

Hypothesis 3 There is a positive relationship between the presence of the remuneration committee and firm performance. 


\section{Research methodology}

The present study covers companies of NSE-500 India. After filtering the sample for financial companies as well as companies for whom data for all years was not available, we were left with 253 non-financial companies for the analysis. The time period considered for the study is ten financial years, i.e., from 2004 to 2013 so as to assess the long term impact of corporate governance mechanism on the financial performance of India. The study followed a quantitative approach to investigate data pertaining to sample companies of NSE 500. The companies belonged to different industries and the time period considered is 2004 to 2013. Since it is a panel data, therefore, we have 2,530 total observations. Data were collected from Centre for Monitoring Indian Economy (CMIE) Prowess Database and corporate governance reports of all companies for the considered period. Since the data belonged to different industries, the study employed two variables, namely leverage and firm age to control company size effect. Industry-wise classification of all sample companies is given in Table 1.

Table 1 Industry-wise classification of companies

\begin{tabular}{lc}
\hline Industry & Number of companies \\
\hline Automobile & 18 \\
Cement and cement products & 10 \\
Chemicals & 10 \\
Construction & 19 \\
Consumer goods & 42 \\
Energy & 24 \\
Fertilisers and pesticides & 10 \\
Healthcare services & 2 \\
Industrial manufacturing & 24 \\
Information technology & 18 \\
Media and entertainment & 3 \\
Metals & 23 \\
Paper & 2 \\
Pharma & 22 \\
Services & 12 \\
Telecom & 4 \\
Textiles & 10 \\
Total & 253 \\
\hline
\end{tabular}

\subsection{Performance measures}

Generally, firm performance is measured of in terms of profits generated by the firm and several studies have considered the variable in different contexts. However, there exists no consensus on one universally accepted definition of the term. In the corporate governance framework, researchers rely on accounting as well as market-based indicators to measure firm performance. The most commonly used accounting measures are Return 
on Assets (ROA), Return on Equity (ROE), and Return on Investment (ROI) as used by Arslan et al. (2014) and Dharmadasa et al. (2014). Tobin's $Q$ (TOQ) has been used by many researchers (Dharmadasa et al., 2014; Nuryanah and Islam, 2011) as market-based measures of firm performance. Tobin's Q is defined as the ratio between a firm's market value and the book value of assets (Okougbo, 2011). Debt is not traded in India therefore; a firm's market value is the sum of the market value of equity and book value of debt. The market value of equity is the product of a number of shares of a firm outstanding in the capital market and the market price of shares. To increase the reliability of our results, based on a literature review, we have included ROA, ROE, and TOQ as measures of firm performance. ROA is the ratio of total income to total assets of a firm; and ROE is the ratio of net income of a firm to its shareholders' equity.

\subsection{Variables of interest}

On the basis of literature review, we have considered the following variables:

- $\quad$ Board size $(B S)$ : Total number of directors on the board of a firm.

- Board composition (BC): It is the proportion of independent directors on the board to the total directors on the board.

- $\quad C E O$ duality (CD): Dummy variable based on the holding of leadership position in the firm. ' 0 ' represents duality while ' 1 ' signifies an absence thereof.

- $\quad$ Promoter shareholding (PS): Percentage of shares held by promoters of the firm.

- Audit committee independence (ACIND): It is the proportion of independent directors in the audit committee.

- $\quad$ Audit committee meetings (ACM): Number of meetings the audit committee holds in a year in a firm.

- $\quad$ Remuneration committee $(R C)$ : It is a dummy variable; ' 0 ' represents the firm does not have a remuneration committee and ' 1 ' signifies the firm have a remuneration committee.

\subsection{Control variables}

Performance of a firm is ascertained by a number of factors. In a corporate governance-performance model, there is a need to control some factors which would otherwise make the relationship unreliable. The selection of these control variables is not easy as there are several factors which may affect the performance of a firm. For the purpose of the present study, two control variables were chosen on the basis of the frequency with which they appear in the literature. In other words, we have chosen the two variables that have been considered in most studies. The control variables taken for the present study are explained below:

- Leverage ( $L E V)$ : It is the ratio of debt to equity. According to the Modigliani-Miller (MM) approach, the capital structure of a firm cannot affect the market value of a firm; but if more debt reduces the agency costs of the firm (by increasing the monitoring by debtholders), then it will have a significant relationship with firm 
performance (Jensen, 1986). Interesting results were reported by many authors when they found the relationship between high leverage and firm performance. The studies provided evidence that high leverage was negatively related with ROA but positively related with TOQ; i.e., it had a negative impact on accounting performance of a firm but a positive influence on the market measure of firm performance (Cheng, 2008). The difference in viewpoints of Jensen (1986) and other authors may be interpreted as a result of over-leverage in firms.

- Firm age (FA): Firm age is calculated as the number of years elapsed since the incorporation of the firm. The relationship between age of the firm and firm performance cannot be established with certainty. Some authors point out that mature firms perform well due to the goodwill developed over time as compared to a new firm (Majumdar, 1997); others suggest that new firms are better than older firms as matured firms fail in adopting new technologies promptly due to their rigidness and sluggishness (Anderson and Reeb, 2003).

\subsection{Model}

The aim of the present study is to determine whether the variables, namely board size, proportion of independent directors on the board, CEO-duality, promoter shareholding, audit committee meetings, percentage of independent directors in audit committee and remuneration committee have a positive impact on dependent variables such as ROA, ROE, and TOQ. First, data mining was done on the basis of descriptive and distributive statistics. Next, correlation analysis was carried out to understand the linear relationship between dependent and independent variables. Finally, a suitable panel linear model was employed to establish the link between corporate governance mechanisms considered and firm performance.

In order to investigate the said relationships, the following mathematical model specification has been used:

$$
Y_{i t}=\alpha+\beta_{i} X_{i t}+\varepsilon_{i t}
$$

where

$Y_{i t}$ takes firm performance variables (ROE, ROA, and TOQ) for each firm ( $i=1$ to 253 firms) at time $(t=2,004$ to 2,103$)$.

$X_{i t}$ takes all the listed independent variables including control ones as mentioned above.

$\varepsilon_{i t} \quad$ is an error term of the model.

In the present study panel, feasible generalised least squares method has been used with a random effect which is considered suitable for testing both company-specific effects (differences between large and others) and correlation over time (Hansen, 2007). In cases where correlation is expected over time, a panel feasible generalised least-square estimator provides or restores efficiency aspects lost in simple OLS (ordinary least square). The method is applied to avoid misleading inferences when there is heteroskedasticity in the sample, i.e., the variances are unequal across panels or there is a problem of autocorrelation within panels.

All the above mentioned methodological estimations were done using $R$ programming language. The derived methodology has been tested for the hypotheses 
proposed earlier. The development of models with respect to the hypotheses proposed is explained below:

a Impact of corporate governance variables (board size, independent directors on the board, duality code, and promoter shareholding) was first estimated along with control variables (leverage and firm age) on each firm performance variables.

b The frequency of audit committee meetings and \% of independent directors in audit committees were checked for any supplementary impact with respect to ROA, ROE, and TOQ.

c Remuneration committee was considered for determining the relationship between the corporate governance components considered and firm performance.

Thus, the study added piece-wise variables for analysis. Results of the analysis are presented in the next section.

\section{Results and discussion}

The data considered in our study is of cross-sectional-time-series nature (panel data). The study considers three dependent variables - ROA, ROE, and TOQ. To test the characteristics of ROA, ROE, and TOQ, data were subjected to skewness, kurtosis, normality (Jarque-Bera test statistics) and panel data unit root tests (Im, Pesaran and Shin, 2003 test statistics - IPS). Generally, panel data displays some form of skewness (herein, ROA, ROE, and TOQ have positive skewness) and kurtosis due to which data will not be normally distributed (as evident from Table 2). Further, since our data exhibit no unit root, there is no need of applying differencing. Results of descriptive statistics of all explanatory variables along with control and dependent variables are given in Table 3.

Table 2 Distributive statistics of dependent variables

\begin{tabular}{lccc}
\hline Statistic & Return on assets (ROA) & Return on equity (ROE) & Tobin's $Q$ \\
\hline (TOQ) & & & \\
Skewness & 0.904 & 14.181 & 6.084 \\
Kurtosis & 7.814 & 225.432 & 51.784 \\
Jarque-Bera & $9,128^{* * *}$ & $77,400,000^{* * *}$ & $13,140,936^{* * *}$ \\
IPS & $-16.96^{* * *}$ & $-14.34^{* * *}$ & $-14.74^{* * *}$ \\
\hline
\end{tabular}

Note: $* * *$ indicates significance at $1 \%$ level.

Descriptive statistics exhibited some unusual results. Like the minimum value of leverage is -19.18 . This might be due to the reason that at some point of time some firm was bearing higher interest on debt than return on investment leading to negative leverage or there would be some brought forward losses which the company must be writing off from the profits of the current year leading to negative shareholders equity and thereby negative leverage. Similarly, the maximum value of ROE is $128.97 \%$ which is also some unusual case. The possible reason behind such value could be due to past losses some company had to bear reduced retained earnings. They might have paid more dividends out of their retained earnings in case of non-availability of sufficient profits which reduced the value of shareholders equity and more return on equity. The board size of 
sample companies ranges from 3 to 22 members with a mean value of ten members on the board. It means that Indian firms on an average have ten board members. It was also observed that independent members on the board range from 0 to $100 \%$ with an average of $52 \%$. Approx. $37 \%$ of sample companies do not have CEO duality, i.e., in $64 \%$ of companies the position of CEO and chairman of the board is held by the same person. Further, it was observed that some government-owned companies have $100 \%$ promoter shareholding whereas no promoters are found in some other companies.

Table 3 Descriptive statistics of all variables

\begin{tabular}{|c|c|c|c|c|c|c|c|}
\hline \multicolumn{2}{|c|}{ Time period } & \multicolumn{3}{|c|}{ 2004-2013 } & \multicolumn{3}{|c|}{$2014-2018$} \\
\hline Variable & Variable description & $\begin{array}{l}\text { Std. } \\
\text { dev. }\end{array}$ & Mean & Median & $\begin{array}{l}\text { Std. } \\
\text { dev. }\end{array}$ & Mean & Median \\
\hline $\mathrm{BS}$ & Board size & 2.87 & 9.85 & 10 & 2.60 & 10.24 & 10 \\
\hline $\mathrm{BC}$ & $\begin{array}{l}\text { Independent directors } \\
\text { on the board }\end{array}$ & 13.04 & 52 & 50 & 13.80 & 49.97 & 50 \\
\hline $\mathrm{CD}$ & CEO duality code & 0.48 & 0.36 & 0 & 0.47 & 0.67 & 1 \\
\hline PS & $\begin{array}{c}\text { Promoter } \\
\text { shareholding }\end{array}$ & 18.36 & 51.4 & 51 & 15.50 & 51.98 & 52.06 \\
\hline $\mathrm{ACM}$ & $\begin{array}{l}\text { Audit committee } \\
\text { meetings }\end{array}$ & 1.59 & 5.01 & 4 & 1.14 & 4.83 & 5 \\
\hline ACIND & $\begin{array}{l}\text { Percentage of } \\
\text { independent } \\
\text { members in audit } \\
\text { committee }\end{array}$ & 17.85 & 84.9 & 100 & 20.74 & 80.23 & 75 \\
\hline $\mathrm{RC}$ & $\begin{array}{l}\text { Remuneration } \\
\text { Committee code }\end{array}$ & 0.44 & 0.73 & 1 & 0.00 & 1.00 & 1 \\
\hline LEV & Leverage & 1.19 & 0.8 & 0.52 & 0.97 & 0.58 & 0.27 \\
\hline FA & Firm's age & 24.90 & 39.95 & 32 & 21.14 & 45.58 & 41.5 \\
\hline ROE & Return on Equity & 6.03 & 0.77 & 0.17 & 0.20 & 0.13 & 0.15 \\
\hline ROA & Return on Assets & 0.08 & 0.09 & 0.07 & 0.11 & 0.06 & 0.07 \\
\hline TOQ & Tobin's Q & 3.16 & 2.22 & 1.32 & 1.71 & 2.31 & 1.83 \\
\hline
\end{tabular}

The range of audit committee meetings held in a year was 0 to 15 with an average of five meetings. The proportion of independent directors in the audit committee was also 0 to 100 which means that some companies are maintaining a highly independent audit committee whereas some companies failed to meet minimum criteria. Although the formation of the remuneration committee was not mandatory before enactment of ICA 2013 , it was observed that approx. $73 \%$ of companies have maintained the remuneration committee voluntarily. In addition, we further included a sample for FY 2014-2018 to explore the changes post the enactment of ICA 2013. The descriptive statistics gave us a glimpse of changes that have taken place post-2013, but, the changes are not significant. The range of board size changed to 5 to 15 members and maximum independent members on the board was $80 \%$. Further, it was observed that $67 \%$ companies have different persons as CEO and Chairman of the board as compared to $37 \%$ and pursuant to SEBI requirement of $10 \%$ minimum public shareholding in listed Public Sector 
companies, wholly owned government companies have reduced their shareholding and the maximum promoter shareholding was $90 \%$. The companies have improved their leverage post-2013 now ranging between 0 and 7 and every company has maintained the remuneration committee to fulfil the mandatory requirement of ICA 2013 (minimum and maximum values are not shown in descriptive statistics table for the sake of brevity).

To determine if the data are homogenous or heterogeneous, data were plotted on a graph (see Figures 1, 2 and 3). Homogeneity/heterogeneity was identified by plotting the considered variables against time (2004-2013). Figures show that data pertaining to ROA and TOQ exhibit more heterogeneity than ROE.

Figure 1 ROA heterogeneity plot w.r.t time factor (see online version for colours)



Figure 2 ROE heterogeneity plot w.r.t time factor (see online version for colours)

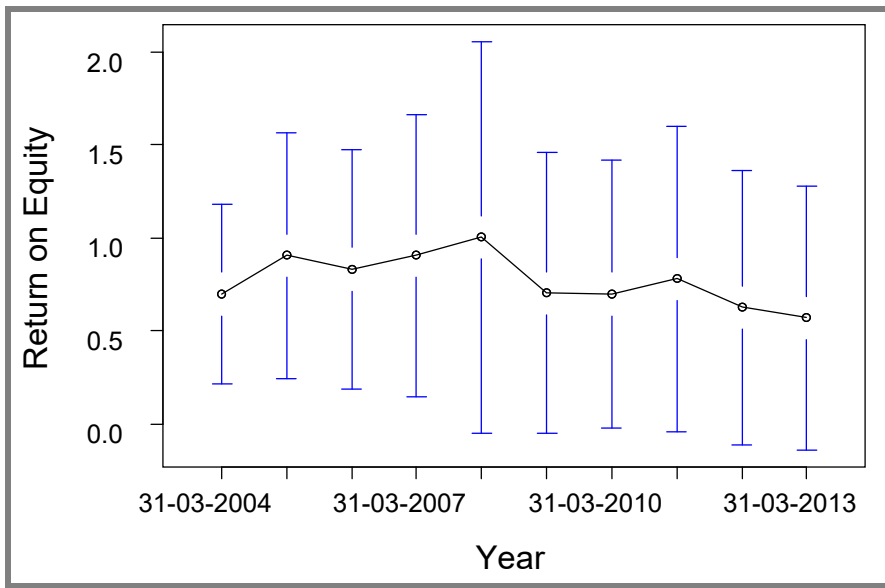


Table 4 Correlation matrix

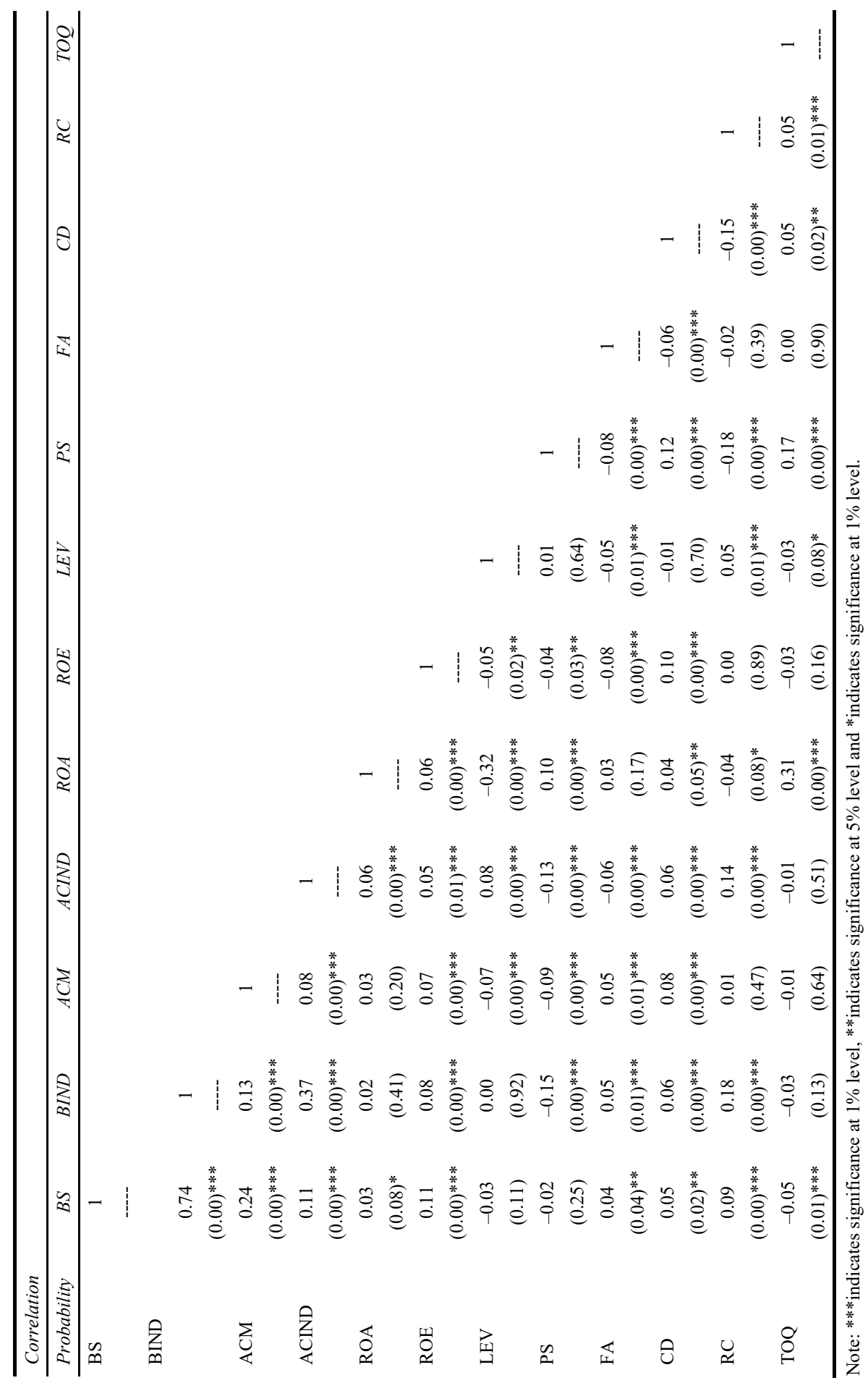


Figure 3 TOQ heterogeneity plot w.r.t time factor (see online version for colours)

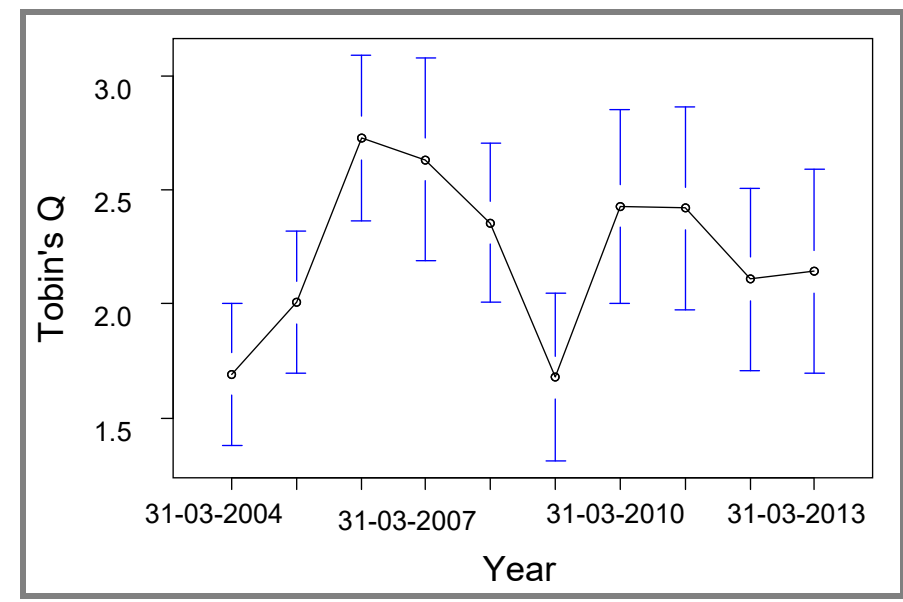

The study also tested for correlations between variables as depicted in the Table 4 . It is clear that except the high correlation between 'board size' and 'independent directors on the board', all other variables exhibit weak to moderate correlations among them. In spite of the observed heterogeneity, errors were found not-normally distributed, supporting the use of panel least squares method over OLS. Further, data pre-testing was done for the period 2014-2018 and data was found fit to perform panel regression. Results have not been presented here for the sake of brevity. Next, the study presents the results of the panel regression models estimated for the data. Results revealed that all models had a good fit. Results of all models are presented in Tables 5, 6, and 7 along with their respective goodness of fit statistics. Finally, all the estimated model results were checked for multicollinearity. The test showed that no problem of multicollinearity existed.

Table 5 Panel feasible generalised least squares model results for ROA

\begin{tabular}{lccccc}
\hline Time period & \multicolumn{2}{c}{$2004-2013$} & Time period & \multicolumn{2}{c}{$2014-2018$} \\
\hline Variable name & Coefficient & p-value & Variable name & Coefficient & $p$-value \\
\hline PS & .001 & $.002^{* * *}$ & BS & .010 & $.000^{* * *}$ \\
ACIND & .001 & $.011^{* * *}$ & BC & -.002 & $.035^{* *}$ \\
FA & -.002 & $.000^{* * *}$ & FA & -.030 & $.004^{* * *}$ \\
LEV & -.013 & $.000^{* * *}$ & LEV & -.068 & $.001^{* * *}$ \\
Multiple R-squared & \multicolumn{2}{c}{$60.10 \%$} & & $50.93 \%$ \\
Durbin Watson test & \multicolumn{2}{c}{2.027} & & \multicolumn{2}{c}{1.69} \\
statistic & \multicolumn{7}{c}{} & & & \\
\hline
\end{tabular}

Note: $* * *$ indicates significance at $1 \%$ level and $* *$ indicates significance at $5 \%$ level.

R-squared measures of all the models show very good explanatory power which indicates that all the models are a good fit. The study also conducted the test for serial correlation (Durbin Watson test statistic). Rule of thumb states that results should be close to two. In our study, all model test statistics came near two, signifying no serial correlation in any of the models. 
Table 6 Panel feasible generalised least squares model results for ROE

\begin{tabular}{|c|c|c|c|c|c|}
\hline \multirow{2}{*}{$\frac{\text { Time period }}{\text { Variable name }}$} & \multicolumn{2}{|c|}{ 2004-2013 } & \multirow{2}{*}{$\frac{\text { Time period }}{\text { Variable name }}$} & \multicolumn{2}{|c|}{$2014-2018$} \\
\hline & Coefficient & p-value & & Coefficient & $p$-value \\
\hline PS & .009 & $.000 * * *$ & $\mathrm{BS}$ & .007 & $.000 * * *$ \\
\hline ACIND & -.003 & $.017 * *$ & $\mathrm{BC}$ & -.002 & $.000 * * *$ \\
\hline FA & -.016 & $.009 * * *$ & ACIND & .001 & $.001 * * *$ \\
\hline \multirow[t]{2}{*}{ LEV } & -.056 & $.000 * * *$ & PS & .001 & $.008 * * *$ \\
\hline & & & LEV & -.065 & $.000 * * *$ \\
\hline Multiple R-squared & \multicolumn{2}{|c|}{$92.50 \%$} & & \multicolumn{2}{|c|}{$48.14 \%$} \\
\hline $\begin{array}{l}\text { Durbin Watson test } \\
\text { statistic }\end{array}$ & \multicolumn{2}{|c|}{1.869} & & \multicolumn{2}{|c|}{1.62} \\
\hline
\end{tabular}

Note: $* *$ indicates significance at $1 \%$ level and $* *$ indicates significance at $5 \%$ level.

Table 7 Panel feasible generalised least squares model results for Tobin's Q

\begin{tabular}{lccccc}
\hline Time period & \multicolumn{2}{c}{$2004-2013$} & Time period & \multicolumn{2}{c}{$2014-2018$} \\
\hline Variable name & Coefficient & $p$-value & Variable name & Coefficient & $p$-value \\
\hline BC & -.064 & $.010^{* * *}$ & BS & .063 & $0.000^{* * *}$ \\
ACM & .045 & $.063^{* *}$ & BC & -.028 & $0.029^{* *}$ \\
LEV & -.073 & $.031^{* *}$ & ACIND & .018 & $0.012^{* *}$ \\
& & & DUALITY & .058 & $0.000^{* * *}$ \\
Multiple R-squared & \multicolumn{2}{c}{$75.00 \%$} & & $45.11 \%$ \\
Durbin Watson Test & \multicolumn{2}{c}{1.976} & & \multicolumn{2}{c}{1.85} \\
Statistic & & & & \\
\hline
\end{tabular}

Note: $* * *$ indicates significance at $1 \%$ level and $* *$ indicates significance at $5 \%$ level.

Results regarding the relationship between independent and dependent variables are discussed below:

- ROA: Results show that leverage and firm's age (control variables) negatively impact ROA. These results are in consonance with that of Olokoyo (2013). However, promoter shareholding and percentage of independent members in audit committee were found to positively impact ROA. Similar results were reported by Carcello et al. (2009) and Klein (1998). The possible reason behind these findings may be that independent directors in the audit committee provide more accurate financial information to other board members, which helps in informed and intelligent decision making. Promoter shareholding positively influences ROA possibly because promoters are major stakeholders, and they would be more concerned with appropriate, effective and efficient use of assets of the firm; to that end, they would try to ensure the best possible utilisation of assets. The frequency of Audit Committee Meetings and other attributes of board structure failed to show any additional impact on ROA. Presence of Remuneration Committee did not show any impact on ROA at all. Thus, results support hypotheses 1(c) and 2(a).

- ROE: We observed that promoter shareholding had a positive impact on ROE while leverage, percentage of independent members in audit committee, and firm age 
showed a negative impact. The probable reason behind this finding might once again be that promoters, being major stakeholders, try to ensure maximum ROE through intelligent investments. Similar results were given by Andres (2008) and Anderson and Reeb (2003). Audit committee meetings, remuneration committee code, board size, board composition and CEO duality were found to have no impact on ROE. Thus, hypothesis $1(\mathrm{c})$ is accepted.

- $\quad$ Tobin's $Q$ : With respect to TOQ, only frequency of audit committee meeting showed a positive impact. Similar results were given by Al-Mamun et al. (2014), Bryan et al., (2004), Menon and Deahl (1994) and Raghunandan and Rama (2007). Independent directors on board and leverage showed a negative impact. These results are in line with those of Balasubramanian et al., (2010) and Sarkar et al., (2006). All other variables had no impact on TOQ. Hence, results support hypothesis 2(b).

The study observed that promoter shareholding shared a positive association with ROA and ROE. These findings have also been supported by existing literature. This shows that promoter shareholding influences the accounting measures of firms, but does not affect the market measure of firm performance. The possible reason behind the negative relationship of leverage with firm performance may be that due to high leverage, cost of capital also increases which reduces firm profit. The finding that older firms tend to earn fewer returns and younger firms earn relatively more may highlight the fact that young firms are more open and adaptable to change which gives them the capability to capitalise on opportunities that older firms are unable to encash.

Consistent with previous studies (Balasubramanian et al., 2010), the present study provides evidence that independent directors on the board do not have a positive association with firm performance. One possible reason for this outcome could be that due to information asymmetry (more information about the company lies with executive directors as compared to independent directors), the efficacy of independent directors gets limited.

It was found that the presence of remuneration committee did not have any impact on the firm's performance. This may suggest a role of other factors such as the composition of the committee, remuneration policy, and compensation provided to executive directors, etc. in addition to only the presence or absence of the remuneration committee.

\subsection{Additional analyses}

In order to further examine the robustness of our results, we extended our study with a sample of the same companies for the period 2014-2018. We examined the impact of the revised code of corporate governance on the financial performance of listed public companies after the enactment of ICA 2013. The regression results are shown in Tables 5, 6 and 7 in the form of comparison with the results of the pre-2013 sample. Overall, the results show that board size has become a significant variable affecting firm performance positively. It is noteworthy that ICA 2013 has restricted the maximum number of members on the board to be 15. Further, the companies act has also recommended that every publicly listed company must have $1 / 3$ independent members in the board and the majority of the sample companies has maintained $50 \%$ or more 
independent members in their boards. But the results show a negative and significant impact of board independence on the financial performance of sample firms. We found that after the enactment of ICA 2013, companies have made changes in their board structure. Earlier there was no such restriction and therefore, both the variables were insignificant in affecting firm performance. The additional analysis shows that significant variables of pre-2013 sample period are more or less same in the post-2013 sample period, which means that the importance of these variables in impacting the financial performance of Indian firms cannot be overlooked and the robustness check confirms our results.

\section{Practical implications}

The major implications for the present study would be that the associations established in this study may be considered a good indicator of relationship mechanisms between corporate governance components and firm performance for similar organisations in lower-middle-income countries. Findings of this study may be useful for organisations similar to the ones considered in the present study. They could attempt to encourage such relationships that have been found to positively influence firm performance. Once the positive relationship between good corporate governance and improved firm performance is understood and adopted by similar organisations or even smaller organisations, they can gain the advantage of increased access to external financing. The investors would be more assured about their investment security and growth. Moreover, the efficiency of the investment decisions of firms is improved.

The relationships observed in the study would also be beneficial for middle-sized companies and SMEs who are not listed on stock exchanges. SMEs consider corporate governance principles to be of little use for them as they have been formulated for large listed companies. After reviewing the suggested relationships in this study, such SMEs could understand the advantage of these relationships for them and must view that it is truly a beneficial tool for all the businesses irrespective of their size in overcoming the challenges of a rapidly changing business environment while maintaining the confidence of stakeholders. It is not only the shareholders that invest their money in any business; there are other stakeholders such as suppliers (by providing credit supply), banks or financial institutions (providing loan), employees (working for the company) etc., who invest their money in companies and are affected by the financial performance of the business (ACCA, 2015). Such companies can also improve their financial performance by applying these governance principles. SMEs can voluntarily adopt such practices to access expert skill, and gain experience and investor confidence. According to ACCA (2015), "Bringing in external independent directors (including non-executive directors NEDs) gives the SME access to a broader range of skills, experience, and personal characteristics. It can also help the SME tap into a wider network of contacts."

The relevance of independent audit committee and frequency of audit committee meetings is suggested through the analysis in the study which pinpoints that if such smaller firms are adopting these policies they can increase their bonding and trust relationship with their stakeholders. 


\section{Conclusions}

\subsection{Main findings of the study}

The present study examines the relationship of corporate governance mechanism with the firm performance of a firm including two underexplored variables - audit committee and remuneration committee. The sample period used in the study to explore the relationship is 2004-2013 and further robustness check of the outcomes was done using the sample period 2014-2018. This was done to identify the impact of new recommendations made in ICA 2013 with respect to corporate governance with the help of pre-2013 data and validation of the results were done using post-2013 data. The empirical analysis of pre-2013 data provided evidence of a positive relationship of promoter shareholding, audit committee independence, and frequency of audit committee meetings to firm performance.

The results are in consonance with the studies of Al-Mamun et al. (2014) Andres (2008) and Carcello et al. (2009). The results reaffirm the importance of independent and active audit committee in improving firm performance of growing economies. However, it failed to provide evidence of any significant relationship of board size, CEO duality and presence of remuneration committee to firm performance.

The results are inconsistent with the findings of Kumar and Singh (2013) and Saibaba and Ansari (2012). The reason behind these contradictions might be that the present study results are based on long-run relationship whereas previous studies either used one year or five years for their analysis. Similarly board independence was also found to have insignificant relation with ROE, but, there is negatively significant relationship with ROA and Tobin's Q. Insignificant relationship of board size to firm performance may be due to the reasons that Indian firms face a large deviation in the board size ranging from 3 to 22 members in the board which makes it difficult to find any kind of relationship.

Although, CEO duality was found to have a positive impact on firm performance the results are insignificant (due to space constraints, insignificant results are not shown here). The possible reason for the positive relationship could be that such firms are enjoying the benefit of the unity of command and there are no chances of conflict between the two positions. Further, in India, the formation of the remuneration committee was not mandatory before the incorporation of companies act in 2013. Still, the majority of the sample companies formed the remuneration committee voluntarily. However, the results found to be negatively and insignificantly associated with firm performance which may be attributed to the reason that such firms do not have fair remuneration committee and must be working under the power of CEO. The study also found that board independence negatively impacts firm performance. The theoretical contribution of the present study is that even though it is assumed that higher independence of the board could reduce the chances of misuse and mismanagement of investor funds but the derived negative relationship gives an insight of information asymmetry between inside directors and outside independence directors. There seems to be high information transaction cost in the firms which is reducing the impact of independence.

Overall, the present study contributes to the existing literature and provides an insight into the corporate governance practices significantly affecting Indian firms with a special emphasis on ICA 2013. The study is unique with respect to its contribution towards two underexplored variables - audit committee and remuneration committee. 


\subsection{Limitations and scope for future research}

All associations in the present study have been tested for underlying linear relationships; however, other tests such as regression trees have not been conducted. Future studies could look to incorporate such tests. Further, more components of corporate governance such as audit committee size, the composition of the remuneration committee, tenure of independent directors, and compensation of executive directors could be tested for their influence on firm performance. Finally, yet importantly, comparative empirical studies using international corporate governance systems of Anglo-American and non-Anglo-American settings and transition economies would add some useful implications for imparting better governance and regulation practices.

\section{References}

Abdel-Meguid, A., Samaha, K. and Dahawy, K. (2014) 'Preliminary evidence on the relationship between corporate governance attributes and audit committee functionality in Egypt: beyond checking the box', Corporate Governance: The International Journal of Business in Society, Vol. 14, No. 2, pp.197-210.

Abdullahi, M., Enyinna, O. and Stella, A. (2010) 'Transparency in corporate governance: a comparative study of Enron, USA and Cadbury PLC, Nigeria', The Social Sciences, Vol. 5, No. 6, pp.471-476.

Al-Mamun, A., Yasser, Q.R., Rahman, M.A., Wickramasinghe, A. and Nathan, T.M. (2014). 'Relationship between audit committee characteristics, external auditors and economic value added (EVA) of public listed firms in Malaysia', Corporate Ownership and Control, Vol. 12, No. 1, pp.899-910.

Al-Najjar, B. (2017) 'Corporate governance and CEO pay: evidence from UK travel and leisure listed firms', Tourism Management, June, Vol. 60, pp.9-14.

Ameer, R., Ramli, F. and Zakaria, H. (2010) 'A new perspective on board composition and firm performance in an emerging market', Corporate Governance: The International Journal of Business in Society, Vol. 10, No. 5, pp.647-661.

Anderson, R.C. and Reeb, D.M. (2003) 'Founding-family ownership and firm performance: evidence from the S\&P 500', The Journal of Finance, Vol. 58, No. 3, pp.1301-1327.

Andres, C. (2008) 'Large shareholders and firm performance - an empirical examination of founding-family ownership', Journal of Corporate Finance, Vol. 14, No. 4, pp.431-445.

Arslan, M., Zaman, R. and Malik, R.K. (2014) 'Impact of CEO duality and audit committee on firm performance: a study of oil and gas listed firms of Pakistan', Research Journal of Finance and Accounting, Vol. 5, No. 17, pp.1697-2222.

Balasubramanian, N., Black, B.S. and Khanna, V. (2010) 'Firm level corporate governance in emerging markets: a case study of India', Emerging Markets Review, Vol. 11, No. 4, pp.319-340.

Bhasin, M. (2012) 'Audit committee mechanism to improve corporate governance: evidence from a developing country', Modern Economy, Vol. 3, No. 7, pp.856-872.

Bhasin, M. (2013) 'Corporate accounting scandal at Satyam: a case study of India's Enron', European Journal of Business and Social Sciences, Vol. 1, No. 12, pp.25-47.

Blue Ribbon Committee on Improving the Effectiveness of Corporate Audit Committees (2002) Report and Recommendations of the Blue Ribbon Committee on Improving the Effectiveness of Corporate Audit Committees.

Brick, I.E. and Chidambaran, N.K. (2010) 'Board meetings, committee structure, and firm value', Journal of Corporate Finance, Vol. 16, No. 4, pp.533-553. 
Brickley, J.A., Coles, J.L. and Jarrell, G. (1997) 'Leadership structure: separating the CEO and chairman of the board', Journal of Corporate Finance, Vol. 3, No. 3, pp.189-220.

Bryan, D., Liu, C. and Tiras, S.L. (2004) The Influence of Independent and Effective Audit Committees on Earnings Quality [online] http://ssrn.com/abstract=2343453 (accessed 20 January 2018).

Carcello, J.V., Klein, A. and Hollingsworth, J.V. (2009) Audit Committee Financial Expertise, Competing Corporate Governance Mechanisms, and Earnings Management [online] http://ssrn.com/abstract=887512 (accessed 22 January 2018).

Casson, M. (1999) 'The economics of the family firm', Scandinavian Economic History Review, Vol. 47, No. 1, pp.10-23.

Chen, J., Cumming, D., Hou, W. and Lee, E. (2013) 'Executive integrity, audit opinion, and fraud in Chinese listed firms', Emerging Markets Review, June, Vol. 15, pp.72-91.

Chen, Z., Cheung, Y.L., Stouraitis, A. and Wong, A.W. (2005) 'Ownership concentration, firm performance, and dividend policy in Hong Kong', Pacific-Basin Finance Journal, Vol. 13, No. 4, pp.431-449.

Cheng, S. (2008) 'Board size and the variability of corporate performance', Journal of Financial Economics, Vol. 87, No. 1, pp.157-176.

Ciftci, I., Tatoglu, E., Wood, G., Demirbag, M. and Zaim, S. (2019) 'Corporate governance and firm performance in emerging markets: evidence from Turkey', International Business Review, Vol. 28, No. 1, pp.90-103.

Claessens, S. and Yurtoglu, B.B. (2013) 'Corporate governance in emerging markets: a survey', Emerging Markets Review, June, Vol. 15, pp.1-33.

Coles, J.L., Daniel, N.D. and Naveen, L. (2008) 'Boards: does one size fit all?', Journal of Financial Economics, Vol. 87, No. 2, pp.329-356.

Conyon, M.J. and Peck, S.I. (1998) 'Board control, remuneration committees, and top management compensation', Academy of Management Journal, Vol. 41, No. 2, pp.146-157.

Daily, C.M. and Dalton, D.R. (1997) 'CEO and board chair roles held jointly or separately: much ado about nothing?', The Academy of Management Executive, Vol. 11, No. 3, pp.11-20.

Dayanandan, A., Donker, H. and Nofsinger, J. (2019) 'The role of caste for board membership, CEO, and interlocking', Pacific-Basin Finance Journal, April, Vol. 54, pp.29-41.

De Andres, P., Azofra, V. and Lopez, F. (2005) 'Corporate boards in OECD countries: size, composition, functioning and effectiveness', Corporate Governance: An International Review, Vol. 13, No. 2, pp.197-210.

Dharmadasa, P., Gamage, P. and Herath, S.K. (2014) 'Corporate governance, board characteristics and firm performance: evidence from Sri Lanka', South Asian Journal of Management, Vol. 21, No. 1, pp.7-31.

Donaldson, L. and Davis, J.H. (1991) 'Stewardship theory or agency theory: CEO governance and shareholder returns', Australian Journal of Management, Vol. 16, No. 1, pp.49-64.

Duru, A., Iyengar, R.J. and Zampelli, E.M. (2016) 'The dynamic relationship between CEO duality and firm performance: the moderating role of board independence', Journal of Business Research, Vol. 69, No. 10, pp.4269-4277.

Efendi, J., Srivastava, A. and Swanson, E.P. (2007) 'Why do corporate managers misstate financial statements? The role of option compensation and other factors', Journal of Financial Economics, Vol. 85, No. 3, pp.667-708.

Elmagrhi, M.H., Ntim, C.G., Crossley, R.M., Malagila, J.K., Fosu, S. and Vu, T.V. (2017) 'Corporate governance and dividend pay-out policy in UK listed SMEs: the effects of corporate board characteristics', International Journal of Accounting and Information Management, Vol. 25, No. 4, pp.459-483.

Fama, E.F. and Jensen, M.C. (1983) 'Separation of ownership and control', Journal of Law and Economics, Vol. 26, No. 2, pp.301-325. 
Field, L.C. and Mkrtchyan, A. (2016) 'The effect of director experience on acquisition performance', Journal of Financial Economics, Forthcoming [online] https://ssrn.com/ abstract=2147169 (accessed 30 April 2018).

Filatotchev, I., Jackson, G. and Nakajima, C. (2013) 'Corporate governance and national institutions: a review and emerging research agenda', Asia Pacific Journal of Management, Vol. 30, No. 4, pp.965-986.

Flannery, N.P. (2011) Problems at Olympus a Sign of Investor Risk at Major Japanese Companies 25 October [online] http://www.forbes.com/sites/nathanielparishflannery/2011/10/25/ a-setting-sun-recent-scandal-at-olympus-a-sign-of-deeper-governance-issues-at-japanesecompanies/\#75f909053e59 (accessed 22 February 2018).

Freeman, R.E. (1984) Strategic Management: A Stakeholder Approach, Cambridge University Press, Cambridge, https://doi.org/10.1017/CBO9781139192675.

Ghasemi, M. and Ab Razak, N.H. (2016) 'Does the size of board of directors and executives affect firm performance in Malaysian listed firms?', International Journal of Economics and Financial Issues, Vol. 6, No. 6S, pp.1-5

Globerman, S., Peng, M.W. and Shapiro, D.M. (2011) 'Corporate governance and Asian companies', Asia Pacific Journal of Management, Vol. 28, No. 1, pp.1-14.

Hansen, C.B. (2007) 'Generalized least squares inference in panel and multilevel models with serial correlation and fixed effects', Journal of Econometrics, Vol. 140, No. 2, pp.670-694.

Hermalin, B.E. and Weisbach, M.S. (2017) 'Assessing managerial ability: implications for corporate governance', The Handbook of the Economics of Corporate Governance, Vol. 1, pp.93-176, Elsevier, North Holland.

Hillman, A.J. and Dalziel, T. (2003) 'Boards of directors and firm performance: integrating agency and resource dependence perspectives', Academy of Management Review, Vol. 28, No. 3, pp.383-396.

Hoskisson, R.E., Wright, M., Filatotchev, I. and Peng, M.W. (2013) 'Emerging multinationals from mid-range economies: the influence of institutions and factor markets', Journal of Management Studies, Vol. 50, No. 7, pp.1295-1321.

Indian Companies Act (2013) New Companies Act [online] http://www.mca.gov.in/MinistryV2/ companiesact.html (accessed 28 October 2017).

Jackson, G. (2010) Understanding Corporate Governance in the United States, Hans-BöcklerStiftung, Dusseldorf.

Jensen, F.H. (1986) 'Recent developments in corporate finance', Federal Reserve Bulletin, November, Vol. 72, p.745.

Jensen, M.C. and Meckling, W.H. (1976) 'Theory of the firm: Managerial behavior, agency costs and ownership structure', Journal of Financial Economics, Vol. 3, No. 4, pp.305-360.

Kao, M F., Hodgkinson, L. and Jaafar, A. (2019) 'Ownership structure, board of directors and firm performance: evidence from Taiwan', Corporate Governance: The International Journal of Business in Society, Vol. 19, No. 1, pp.189-216.

Kaymak, T. and Bektas, E. (2008) 'East meets West? Board characteristics in an emerging market: evidence from Turkish banks', Corporate Governance: An International Review, Vol. 16, No. 6, pp.550-561.

Khan, A., Tanveer, T. and Malik, U. (2017) 'An empirical analysis of corporate governance and firm value: evidence from KSE-100 index', Accounting, Vol. 3, No. 2, pp.119-130.

Klein, A. (1998) 'Firm performance and board committee structure 1', The Journal of Law and Economics, Vol. 41, No. 1, pp.275-304.

Krenn, M. (2014) 'CEO duality: economic and socio-psychological determinants', Journal of Leadership, Accountability and Ethics, Vol. 11, No. 3, p.141.

Kueppers, R.J. and Sullivan, K.B. (2010) 'How and why an independent audit matters', International Journal of Disclosure and Governance, Vol. 7, No. 4, pp.286-293. 
Kumar, N. and Singh, J.P. (2013) 'Effect of board size and promoter ownership on firm value: some empirical findings from India', Corporate Governance: The International Journal of Business in Society, Vol. 13, No. 1, pp.88-98.

Laksmana, I. (2008) 'Corporate board governance and voluntary disclosure of executive compensation practices', Contemporary Accounting Research, Vol. 25, No. 4, pp.1147-1182.

Leung, S., Richardson, G. and Jaggi, B. (2014) 'Corporate board and board committee independence, firm performance, and family ownership concentration: an analysis based on Hong Kong firms', Journal of Contemporary Accounting and Economics, Vol. 10, No. 1, pp.16-31.

London Stock Exchange (UK) (1998) Committee on Corporate Governance Final Report, Gee Publishing Ltd., London.

Majumdar, S.K. (1997) 'The impact of size and age on firm-level performance: some evidence from India', Review of Industrial Organization, Vol. 12, No. 2, pp.231-241.

McConnell, J.J., Servaes, H. and Lins, K.V. (2005) Changes in Equity Ownership and Changes in the Market Value of the Firm [online] http://ssrn.com/abstract=470927 (accessed 22 January 2018).

Menon, K. and Deahl, W.J. (1994) 'The use of audit committees for monitoring', Journal of Accounting and Public Policy, Vol. 13, No. 2, pp.121-139.

Meyer, E. and de Wet, JHvH. (2013) 'The impact of board structure on the financial performance of listed South African companies', Corporate Board: Role, Duties and Composition, Vol. 9, No. 3, pp.19-31.

Mukherjee, S. (n.d) Corporate Governance in India: Need, Importance and Conclusion [online] http://www.economicsdiscussion.net/business-environment/corporate-governance/ corporate-governance-in-india-need-importance-and-conclusion/10145 (accessed 18 October 2017).

Murphy, K.J. (1999) 'Executive compensation', Handbook of Labor Economics, Vol. 3, pp.2485-2563, Elsevier, North Holland.

Nuryanah, S. and Islam, S. (2011) 'Corporate governance and performance: evidence from an emerging market', Malaysian Accounting Review, Vol. 10, No. 1, pp.17-42.

O'Sullivan, M., Percy, M. and Stewart, J. (2008) 'Australian evidence on corporate governance attributes and their association with forward-looking information in the annual report', Journal of Management and Governance, Vol. 12, No. 1, pp.5-35.

Okougbo, P.O. (2011) Corporate Governance and Firm Performance: Empirical Evidence from Selected Listed Companies in Nigeria, Doctoral dissertation, Covenant University, Ota.

Olokoyo, F.O. (2013) 'Capital structure and corporate performance of Nigerian quoted firms: a panel data approach', African Development Review, Vol. 25, No. 3, pp.358-369.

Pamburai, H.H., Chamisa, E., Abdulla, C. and Smith, C. (2015) 'An analysis of corporate governance and company performance: a South African perspective', South African Journal of Accounting Research, Vol. 29, No. 2, pp.115-131.

Paniagua, J., Rivelles, R. and Sapena, J. (2018) 'Corporate governance and financial performance: the role of ownership and board structure', Journal of Business Research, August, Vol. 89, pp.229-234 (accessed August 2018).

Prentice, R.A. and Spence, D.B. (2007) 'Sarbanes-Oxley as quack corporate governance: how wise is the received wisdom?', Georgetown Law Journal, McCombs Research Paper Series No. IROM-10-06 [online] https://ssrn.com/abstract=945796 (accessed 30 April 2018).

Pucheta-Martinez, M.C. and de Fuentes, C. (2007) 'The impact of audit committee characteristics on the enhancement of the quality of financial reporting: an empirical study in the Spanish context', Corporate Governance: An International Review, Vol. 15, No. 6, pp.1394-1412.

Raghunandan, K. and Rama, D.V. (2007) 'Determinants of audit committee diligence', Accounting Horizons, Vol. 21, No. 3, pp.265-279. 
Rhoades, D.L., Rechner, P.L. and Sundaramurthy, C. (2001) 'A meta-analysis of board leadership structure and financial performance: are 'two heads better than one'?', Corporate Governance: An International Review, Vol. 9, No. 4, pp.311-319.

Saibaba, M.D. and Ansari, V.A. (2012) 'Impact of board size: an empirical study of companies listed in BSE 100 index', Indian Journal of Corporate Governance, Vol. 5, No. 2, pp.108-119.

Sarkar, J. and Sarkar, S. (2008) 'Debt and corporate governance in emerging economies evidence from India', Economics of Transition, Vol. 16, No. 2, pp.293-334.

Sarkar, J., Sarkar, S. and Sen, K. (2006) 'Board of directors and opportunistic earnings management: evidence from India', Journal of Accounting, Auditing and Finance, Vol. 23, No. 4, pp.269-286.

Schiehll, E. and Martins, H.C. (2016) 'Cross-national governance research: a systematic review and assessment', Corporate Governance: An International Review, Vol. 24, No. 3, pp.181-199.

Securities and Exchange Commission Bangladesh (2012) Notification, 7 August [online] http://www.secbd.org/Notification\%20on\%20CG-07.8.12-Amended.pdf (accessed 25 February 2018).

Securities Commission Malaysia (2012) Malaysian Code on Corporate Governance 2012 [online] http://www.sc.com.my/wp-content/uploads/eng/html/cg/cg2012.pdf (accessed 12 March 2018).

Sen, P.K., Das, D. and Sharma, P. (2014) 'Relevance of financial literacy for the growth of national economy and elimination of frauds', The MA Journal, Vol. 49, No. 6, pp.41-44.

Singh, J.P., Kumar, N. and Uzma, S. (2010) 'Satyam fiasco: Corporate governance failure and lessons there from', IUP Journal of Corporate Governance, Vol. 9, No. 4, pp.30-39.

Smaraidos, V., Thanasas, G.L. and Filiou, A. (2018) 'The impact of corporate governance on earnings management in emerging economies: the Greek evidence', International Journal of Comparative Management, Vol. 1, No. 3, pp.317-330.

Stock Exchange of Thailand (2012) The Principles of Good Corporate Governance for Listed Companies 2012 [online] www.set.or.th/sustainable_dev/th/cg/files/2013/ CGPrinciple2012Thai-Eng.pdf (accessed 25 February 2018).

The Association of Chartered Certified Accountants (2015) Governance for All: The Implementation Challenge for SMEs, June [online] http://www.accaglobal.com/content/dam/ acca/global/PDF-technical/small-business/ea-governance-for-all.pdf (accessed 14 June 20118).

The Securities and Exchange Commission of Sri Lanka and The Institute of Chartered Accountants of Sri Lanka (2013) Code of Best Practice on Corporate Governance [online] http://www.sec.gov.lk/wp-content/uploads/code\%20of\%20best $\% 20$ practice\%20-\%202013.pdf (accessed 13 May 2018).

Tosi Jr., H.L. and Gomez-Mejia, L.R. (1989) 'The decoupling of CEO pay and performance: an agency theory perspective', Administrative Science Quarterly, Vol. 34, No. 2, pp.169-189.

Ujunwa, A. (2012) 'Board characteristics and the financial performance of Nigerian quoted firms', Corporate Governance: The International Journal of Business in Society, Vol. 12, No. 5, pp.656-674.

Yuan, Z. (2011) Corporate Governance and Directors' Independence, Kluwer Law International $\mathrm{BV}$, Netherland.

Zhang, Y., Zhou, J. and Zhou, N. (2007) 'Audit committee quality, auditor independence, and internal control weaknesses', Journal of Accounting and Public Policy, Vol. 26, No. 3, pp.300-327. 